\title{
INTERNATIONAL REVIEW OF APPLIED LINGUISTICS IN LANGUAGE TEACHING IRAL
}

\section{EDITORS}

Peter Jordens

Max Planck Institute for Psycholinguistics

Nijmegen, The Netherlands

E-mail: peter.jordens@mpi.nl

Leah Roberts

University of York

United Kingdom

E-mail: leah.roberts@york.ac.uk 
Kathleen Bailey, Monterey Institute of International Studies, USA

Inge Bartning, Stockholm University, Sweden

Theo Bongaerts, University of Nijmegen, The

Netherlands

Mirjam Broersma, Radboud University Nijmegen, The Netherlands

Susanne Carroll, University of Potsdam, Germany

Aoju Chen, Utrecht University, The Netherlands

Graham Crookes, University of Hawaii, Honolulu, USA

Annick De Houwer, University of Antwerp, Belgium Christine Dimroth, University of Münster, Germany Tess Fitzpatrick, Cardiff University, UK Aline Godfroid, Michigan State University, USA Nicholas Groom, University of Birmingham, UK
Marianne Gullberg, Center for Languages and Literature, Lund University, Sweden

Pieter de Haan, Radboud

University, Nijmegen, The

Netherlands

Henriette Hendriks,

Research Centre for English and Applied Linguistics, Cambridge, UK Alex Housen, Free University of Brussels, Belgium Allan James, University of Klagenfurt, Austria Eric Kellerman, Radboud University, The Netherlands

Keiko Koda, Carnegie Mellon University, Pittsburgh, USA Patsy Lightbown, Concordia University, Montreal, Canada Sarah Liszka, University of Greenwich, UK

Emma Mardsen, University of York, UK
Paul Meara, Swansea

University, UK

Carmen Muñoz, University of Barcelona, Spain

Rebecca Oxford, University of Maryland, USA

Peter Robinson, Aoyama

Gakuin University, Tokyo, Japan

Sarah Schimke, University of Osnabrück, Germany

Yasuhiro Shirai, University of Pittsburgh, USA

Danijela Trenkic, University of York, UK

Martha Young-Scholten, Newcastle University,

UK

Johannes Wagner,

University of Southern

Denmark, Odense,

Denmark

Keiko Yoshioka, University of Leiden, The Netherlands Boping Yuan

University of Cambridge, UK 
ABSTRACTED/INDEXED IN British Education Index, Celdes, CNKI Scholar (China National Knowledge Infrastucture), CNPIEC, De Gruyter - Dietrich's Index Philosophicus, De Gruyter IBR (International Bibliography of Reviews of Scholarly Literature in the Humanities and Social Sciences), De Gruyter - IBZ (International Bibliography of Periodical Literature in the Humanities and Social Sciences), DELTAA The database on English Language Teaching for Adults in Australasia, EBSCO - Academic Search, EBSCO - Book Review Digest Plus (Wilson), EBSCO - Communication and Mass Media Complete, EBSCO - Education Abstracts (Wilson), EBSCO - Education Research Complete/Education Source, EBSCO - MasterFILE, EBSCO - OmniFile (Wilson), EBSCO Periodicals Collection, EBSCO - Professional Development Collection, EBSCO - Teacher Reference Center, EBSCO - TOC Premier, EBSCO Discovery Service, Educational Research Abstracts Online, Elsevier - SCOPUS, ERIC (Education Resources Information Center), ERIH European Reference Index for the Humanities, Gale/Cengage - Academic One File, Google Scholar, Informationszentrum für Fremdsprachenforschung (IFS), INIST Institut de 1'Information Scientifique et Technique, J-Gate, Linguistics Abstracts Online, MLA International Bibliography, Naviga (Softweco), Primo Central (ExLibris), ProQuest - Deep Indexing: Technical Information, ProQuest - Education Journals, ProQuest - Linguistics \& Language Behavior Abstracts (LLBA), ProQuest - Periodicals Archive Online, ProQuest - Periodicals Index Online, SCImago (SJR), Summon (Serials Solutions/ProQuest), TDOne (TDNet), UB Frankfurt - BLL Bibliographie Linguistischer Literatur, UB Frankfurt - OLC Linguistik, WorldCat (OCLC).

The publisher, together with the authors and editors, has taken great pains to ensure that all information presented in this work reflects the standard of knowledge at the time of publication. Despite careful manuscript preparation and proof correction, errors can nevertheless occur. Authors, editors and publisher disclaim all responsibility and for any errors or omissions or liability for the results obtained from use of the information, or parts thereof, contained in this work.

ISSN 0019-042X · e-ISSN 1613-4141

All information regarding notes for contributors, subscriptions, Open access, back volumes and orders are available online at www.degruyter.de/journals/iral/detail.cfm.

RESPONSIBLE EDITOR Leah Roberts, Department of Education, University of York, Heslington, York, YO10 5DD, United Kingdom, E-mail: leah.roberts@york.ac.uk

JOURNAL MANAGER Andrea Lutz, De Gruyter, Genthiner Straße 13, 10785 Berlin, Germany, Tel.: +49 (0)30 26005 - 229, Fax: +49 (0)30 26005 - 250,

Email: Andrea.Lutz@degruyter.com

RESPONSIBLE FOR ADVERTISEMENTS Claudia Neumann, De Gruyter, Genthiner Straße 13, 10785 Berlin, Germany. Tel.: +49 (0)30 26005 - 226, Fax: +49 (0)30 26005 - 322,

Email: anzeigen@degruyter.com

C 2014 Walter de Gruyter GmbH, Berlin/Boston

TYPESETTING Asco Typesetters, Hong Kong

PRINTING Franz X. Stückle Druck und Verlag e.K., Ettenheim Printed in Germany

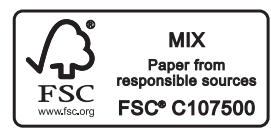




\section{Contents}

Sylviane Granger and Yves Bestgen

The use of collocations by intermediate vs. advanced non-native writers:

A bigram-based study -229

Mike Sharwood Smith and John Truscott

Explaining input enhancement: a MOGUL perspective -253

Patti Spinner and Jamie A. Thomas

L2 learners' sensitivity to semantic and morphophonological information on Swahili nouns - 283 